\title{
12 Unraveling the political economy of coal
}

\author{
Insights from Vietnam ${ }^{1}$
}

\author{
Ira Irina Dorband, Michael Jakob, and Jan C. Steckel
}

\section{Introduction}

Vietnam envisages a substantial ramp-up of coal-fired electricity generation capacity to fuel its economic growth based on energy-intensive production (Tang et al., 2016). With a projected installed capacity of more than $49 \mathrm{GW}$ by 2030, coal capacity would more than quadruple from 2015 levels (c.f. Figure 12.1). However, these investments in coal in Vietnam are far from obvious from an environmental or a purely techno-economic perspective as they entail large public health costs, increased import dependence and underuse of the country's large potential of renewable electricity generation (Koplitz et al., 2017; Nangia, 2019; UNDP, 2019). As we demonstrate in this chapter,Vietnam's climate and energy policies are to a large part determined by political economy factors, such as the Communist Party's urge to assert its power and the influence of incumbent interest groups.

Since Vietnam's reunification in 1976, the Communist Party of Vietnam (CPV) has been ruling in a one-party regime. During the past three decades of fast and energy-intensive economic growth, Vietnam passed the middleincome country threshold in 2011 (World Bank, 2019b), while electricity demand grew by $10-11$ percent per year on average. Despite continued privatization and reform efforts, industrial sectors, including the electricity market, remain largely government-controlled. The type and location of new power plants included in the five-year power development plans (PDPs) are centrally decided by the Ministry of Industry and Trade ("Energy Ministry" ff.) and its provincial counterparts. The state-owned monopoly utility Vietnam Electricity $(\mathrm{EVN})$ under the Energy Ministry functions as a single buyer of electricity and controls most of the transmission; together with two other state-owned enterprises (SOEs) in the energy sector, it controls 90 percent of generation capacity (ADB, 2015). The Online Appendix provides a detailed country background.

In this interview-based case study, we aim to identify the political factors that shape Vietnam's climate and energy policies, shedding light on otherwise hidden interrelations, vested interests and underlying power struggles behind Vietnam's coal plans. The literature identifies three high-level political goals that 
Vietnam 211

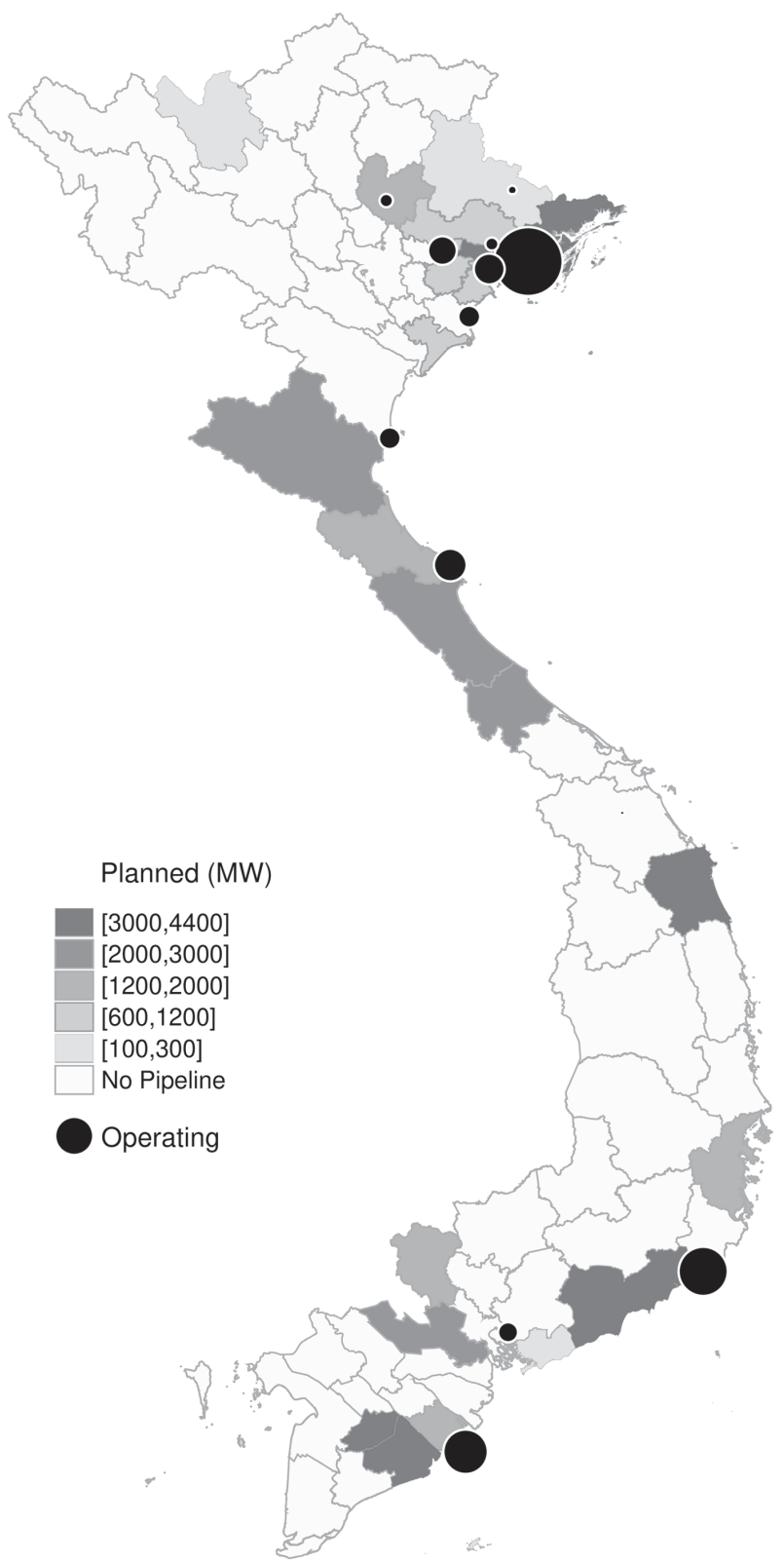

Figure 12.1 Operating and planned coal-fired electricity generation capacity inVietnam until 2030.

Note: total operating $18 \mathrm{GW}$; "planned" subsumes announced, pre-permitted, permitted and plants under construction.

Source: Shearer et al. (2020). 


\section{Ira Irina Dorband et al.}

are primarily guiding national energy policy, affordability, security of supply and (environmental) sustainability (c.f. Joas et al., 2016; Johnstone et al., 2017; Schmidt et al., 2019), as well as, fourth, the promotion of the domestic energy industry (Jenkins, 2014; Schmidt et al., 2019). Focusing on the political perspective, we explain how these four general goals of energy policy translate into the choice for coal in Vietnam.

There are some studies analyzing climate and energy policies in Vietnam, and some studies examining the political economy of coal in other countries. However, to our knowledge, there is no systematic analysis of the complex entanglement of domestic and international interests and stakeholders around the coal sector in Vietnam. In interview-based analyses, Urban et al. (2018) identify the legislative shortcomings, but not the underlying political determinants, of the various existing sustainability and energy strategies from an environmental justice perspective. Examining the drivers for passing these strategies, Zimmer et al. (2015) emphasize the role of international agencies and briefly discuss how close ties and potential vested interests between ruling elites and energy state-owned enterprises (SOEs) might hamper the strategies' implementation. In a detailed analysis of Vietnamese energy sector developments, Neefjes and Thi Thu Hoai (2017) find that the Energy Ministry and fossil energy SOEs together have the greatest agency in promoting coal. They also point out that civil society organizations exert weak influence. Our study is the first to systematically tease out the underlying objectives of domestic and international actors, the way in which Vietnam's governance context allows them to influence policymaking and how this constellation results in the increasing use of coal in Vietnam's power sector.

\section{Method}

In order to make our approach as transparent as possible, we follow the best practice for qualitative data collection (c.f. Bogner et al., 2018) and build our analysis on the political economy framework (Jakob et al., 2020) further explained in Chapter 1. For the purpose of empirical data collection inVietnam, we operationalized the theoretical framework in qualitative semi-structured expert interviews, following the approach described by Bogner et al. (2018). Relevant stakeholders in Vietnam were identified based on desk research and pre-interviews, which also served to test and improve the interview guideline. In April 2018, we interviewed 30 stakeholders in 25 semi-structured interviews in Hanoi and Ho Chi Minh City.Very few institutions declined our invitation, so, with the exception of two SOEs, we gathered data across a broad sample of stakeholders (refer to Online Appendix for Table A12.1 of interviews by sector). Finally, we distilled and synthesized the key insights informing our research questions from the interview transcripts and notes. ${ }^{2}$

In order for this analysis to minimize research bias, we exclude normative or opinion-based statements if they are only brought forward by one interviewee and could not be supported by secondary sources, such as news articles or grey 
literature reports. However, distinguishing between opinion- and fact-based information is partially based on the authors' judgment because "objective" information on many aspects of Vietnam's energy sector and climate policy remains scarce due to the lack of transparency and disclosure - which in itself is part of the motivation for this case study.

\section{Results: political economy determinants of coal use}

Vietnam's focus on coal as the main source of electricity generation is driven by a complex web of actors and institutions with different objectives and means of political influence, embedded in the overall socio-economic and political context. In the following, we analyze how the choice for coal is determined by the interplay between the key actors shaping Vietnam's climate and energy policies. These include ministries and political institutions (political (p)), businesses and investors (business (b)), domestic civil society (societal national (sn)) and international organizations (societal international (si)) (c.f. Table A12.1 in Online Appendix). In our interviews, these actor groups mentioned a variety of objectives influencing Vietnam's electricity policy. We cluster these into four highlevel strategic objectives: affordability, security of supply, the promotion of the domestic energy industry and personal interests, as well as climate and environmental considerations.

Figure 12.2 depicts the share of interviewees in each group who mentioned the respective high-level energy policy objective to strongly influence energy decisions in Vietnam. These do not necessarily coincide with their own priorities. Even though this simple counting does not allow for directly inferring the true importance of a certain objective, it is useful in order to systematically structure the main insights from the interviews. ${ }^{3}$ Affordability was mentioned by most actors, emphasized strongest by business actors. Security of supply was highlighted most strongly by political and international actors. A substantial share of the national civil society and business representatives discussed the goal to promote the national energy industry, which was rarely mentioned by political representatives. Finally, climate and environmental goals (or their weakness) were most frequently put forward not only by domestic civil society but also by half of the political actors interviewed.

\section{Affordability}

Keeping electricity prices low for citizens and energy-intensive, especially stateowned, industries was often mentioned as the single most important objective in the sector and as a pivotal strategic interest of the CPV to preserve its power [b1, b2, b4, b6, si1, p5, p6]. According to the communist heritage, providing affordable basic utilities to the people is a major factor for the Party's legitimization of power [si1].

Electricity tariffs are regulated by the government at a rate below cost recovery (c.f. Gerner et al., 2018; Maweni \& Bisbey, 2016) and differentiated 


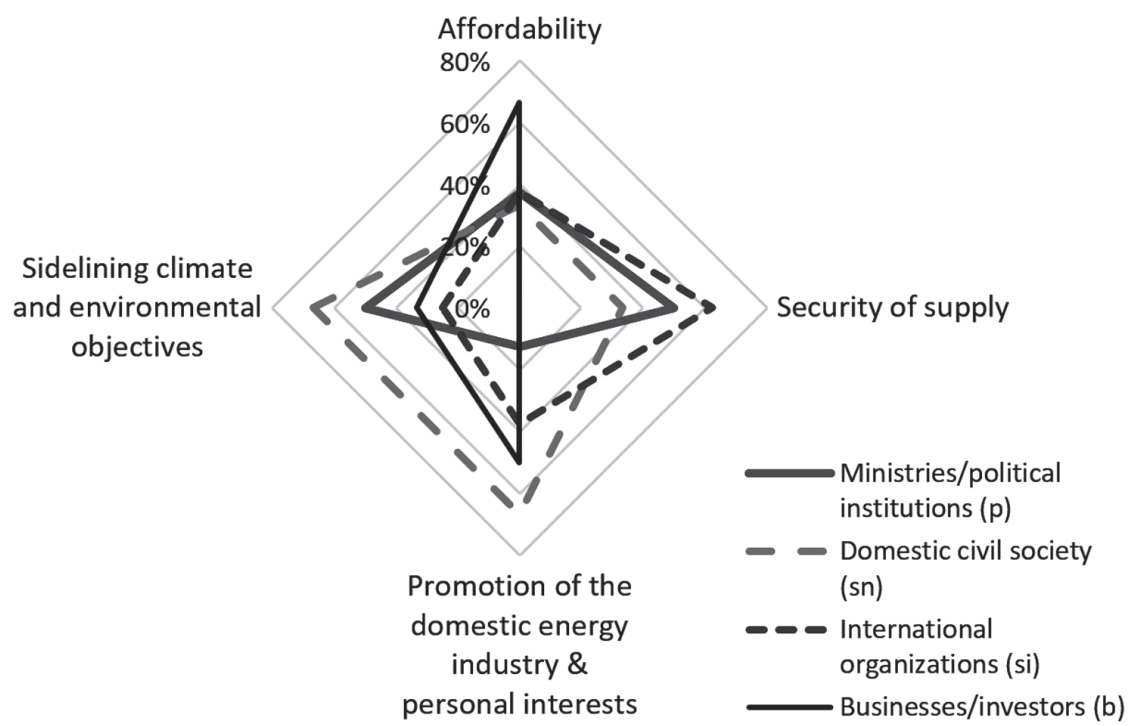

Figure 12.2 Strategic objectives affecting Vietnam's energy policy.

Note: shares of interviewees by category highlighting the respective objectives to be very influential for energy sector decisions in Vietnam.

by consumer type. Industry and residential users together account for around 90 percent of electricity consumption in Vietnam (EVN, 2018; IEA, 2017). Tariffs are lowest for the manufacturing industry, including the SOE-dominated energy-intensive steel, fertilizer and cement sectors, and public administration institutions, and highest for commercial businesses (EVN, 2019). Even though nominal tariffs were increased in 2017 [b2] and 2019, the raise was outpaced by inflation and rising generation costs (Gerner et al., 2018) [b1, b5]. Thus, in the period of 2012-2017, indirect subsidies effectively rose from about US $\varnothing$ 1.3 to 2 per $\mathrm{kWh}$ (i.e. 25 percent of the average 2019 tariff of US $\varnothing 8$ per kWh (VND 1,860) (Vu, 2019)) [si5, b5]. In 2017, the total subsidy was roughly USD 3.5 billion (based on EVN, 2018). The government does not show any commitment to a clear tariff Reform Roadmap, beyond correcting for inflation, while indirect subsidies are likely to rise further as Vietnam's cheap hydropower sources have mostly been exploited [b1, p4]. The political goal of low electricity prices is influencing decisions concerning the electricity generation mix in several ways.

Lack of systematic cost analyses of capacity additions

Constrained price-setting results in a bias toward capacity additions with the lowest perceived cost. The Law on Bidding, issued by the Ministry of Finance 
("Finance Ministry" ff.) mandates that the bid chosen has the lowest levelized electricity cost (LCOE). However, the Energy Ministry does not practice competitive tendering but chooses this lowest price from mostly unsolicited bids [sn1]. In 2014, when the current five-year power development plan, PDP VII Revised, was initially drafted, the LCOE of coal was indeed lower than that of alternative fuels [si1]. However, the reported LCOE might not even reflect the economic costs of coal-fired generation in a narrow sense (i.e. disregarding the adverse environmental and public health effects). Operation and maintenance costs, such as coal imports at increasing international prices as well as repair services, are often not considered. Furthermore, the Energy Ministry does not test the bids' compliance with minimum environmental standards [p8]. As a consequence, subcritical coal facilities, fueled with lower quality domestic coal, and often using cheaper, but less durable, Chinese equipment, may appear to decisionmakers to be the most cost-effective capacity additions [si4, b4] (GreenID, 2018). This is one reason why coal-fired power plants are preferred over technologies that face higher upfront, but low operation costs, such as renewables.

\section{Credit-constrained energy SOEs, subsidies and public debt}

Because electricity tariffs are regulated below cost recovery, both the monopoly state-utility EVN and the state coal extraction and import firm Vietnam National Coal and Mineral Industries Group (Vinacomin) completely rely on government capital, which significantly contributes to Vietnam's increasing public debt $[\mathrm{b} 1, \mathrm{~b} 2]$. The SOEs' financial risks mainly originate from operational inefficiencies, high levels of debt financing and related exchange rate risks (primarily to the Japanese Yen, the Chinese RMB and the USD) (Maweni \& Bisbey, 2016). EVN's capital expenditure has typically been as much as 95 percent debt financed; however, its debt servicing requirements are not reflected in electricity tariffs (Gerner et al., 2018). As a result, state capital injections of approximately USD 3-4 billion were needed for EVN and USD 1.5 billion for Vinacomin (News VietNamNet, 2016).

The Party's efforts to keep tariffs low have furthermore resulted in a substantial increase in indirect subsidies for coal from USD 37 million in 2015 to USD 160 million in 2017 (excluding externalities) (IEA, 2018). The price of thermal coal paid by coal-consuming SOEs is subject to negotiations with the Energy Ministry and Vinacomin [b3]. As a result, domestic coal prices for thermal power, steel and cement production are artificially low [b1, p3], around 30 percent lower than import prices in 2015 (GreenID, 2018). One interviewee estimated subsidies to the power sector as a whole to amount to 5.5 percent of GDP, that is, roughly USD 10 billion in 2017 (excluding externalities) [b4]. The subsidized price gap is likely to grow due to increasing extraction costs of domestic reserves and fluctuating international prices of coal imports $[b 4, b 3$, p3]. These SOE liabilities translate into implicit fiscal costs and have decisively contributed to the government reaching its self-imposed debt ceiling of 65 percent of GDP in 2017 [b1]. 
Slow progress on electricity sector reform

In order to reduce the losses by state-owned power producers (and the associated budget deficit), there is increasing pressure to follow the Roadmap for Power Sector Reforms. ${ }^{4}$ The Finance and the Planning Ministries strongly support the liberalization of the electricity market [si3, si4]. Despite reform plans, EVN's three generation companies, together with the SOEs Vinacomin and Vietnam Oil and Gas Group (PVN), control 90 percent of the generation (ADB, 2015). The first initial public offering of a generation company was largely unsuccessful, selling only a fraction of the offered shares due to the company's high indebtedness and the fact that EVN remains the majority shareholder with equitization capped at 49 percent [si3, sn3]. Due to the cap, generation companies have limited access to international capital markets even after the offering.

While the unsuccessful equitization process is also due to a lack of human capacity in the government [p7, si4], several interviewees emphasized that an underlying reason might be that some parts of the CPV actually oppose liberalizing the power sector to maintain EVN's monopoly status [b4, b1, si1, si5, b6]. Referring to the Reform Roadmap, a government-related interview partner said, "In the paper [sic], the government wants to open the energy market, but only in paper [sic]" [p8]. This opposition might be driven by vested interests in connection with the SOEs (see the "Promotion of the domestic energy industry and personal interests" section). Another reason is the regime's communist heritage whereby the Party takes responsibility for providing affordable electricity to the population and maintaining regulatory superiority over vital infrastructure [si1, si8]. Hence, the CPV's reluctance to increase electricity prices and its related concerns about public opposition impedes power market reform. Yet conversely, the population opposes price or tax increases mostly because they distrust the government and EVN due to the operational inefficiencies and the lack of transparency on how revenues are spent [si5, si6] (UNDP, 2019).

\section{Tighter requirements for limited government guarantees}

Budget consolidation efforts and increasing pressure to restructure the energy SOEs decisively affect investments in electricity generation [si6]. As lossmaking entities, the SOEs depend on government guarantees to access foreign investment loans [sn1]. In mid-2018, the Law on Public Debt Management introduced a cap on the overall value of government-guaranteed foreign loans and increased the equity requirements [si3]. As a consequence, EVN is itself no longer able to invest in capacity additions [b4]. As part of the restructuring process, Vinacomin and PVN are encouraged to focus on their core business activities, which do not necessarily include power plants - of which they owned 14 percent of capacity in 2015 (Maweni \& Bisbey, 2016). Consequently, the substantial increase in generation capacity envisaged in the PDP VII Revised relies largely on investments by (international) independent power producers. 
Dependence on independent power producers and high investment risks

Due to the described financial and structural constraints, most generation capacity additions are expected to come from, primarily international, independent power producers (IPPs) [si4, p2, si5]. Independent producers can, however, face high investment risks [si3]. While IPPs control only 7 percent of the current fleet of power plants, the PDPVII Revised expects them to account for 60 percent of the roughly USD 90 billion total investment needs in capacity additions until 2030 (Gerner et al., 2018).

Investment risks in the electricity sector remain high and attractive only for certain investors [si8]: IPPs depend on EVN for power purchase agreements (PPAs), grid connection ${ }^{5}$ and payments for electricity sold [sn3, si5, sn1].Thermal power producers additionally depend on Vinacomin for coal supplies - which have recently fallen short of demand (VnExpress, 2018). EVN and Vinacomin remain highly indebted and have an interest in prioritizing their own generation facilities. The risk of nonpayment can only be mitigated by the government underwritings [si1]. Most importantly, PPAs remain weak and non-bankable, due to curtailment, termination and arbitration clauses [si3, sn3]. For example, while the relatively generous 20-year solar feed-in tariff (FiT) of approximately US $\not 9.35 / \mathrm{kWh}$ is considered sufficiently high to attract investors, the associated PPA includes neither protection against retroactive changes in policy nor hedging options for longer than one year. Additionally, its legal backing and arbitration clauses are weak [b1, b4, si3, sn3].

Existing guarantees for renewable investments are insufficient to enable most international banks or private lenders to provide project finance [b4, si3]. The unstable regulatory framework thus contributes to the investment gap to realize renewable energy projects as intended under PDP VII Revised [si8, b1, p8]. While Vietnamese banks have found the PPAs sufficient for financing, albeit, at interest rates of 8-9 percent with additional informal charges, local investors often lack adequate equity capacity [b1, b4, si2]. Joint ventures of international and domestic firms with financing from Vietnamese banks might provide a feasible option for renewable energy development [si3]. Indeed, as of June 2019, 4.5 GW of solar capacity had been completed (Viet Nam News, 2019), and as of November 2018, at least 12 GW of solar projects had received some type of official approval, mainly developed by domestic investors with some international participation.

\section{Regulatory bias of investment risk reduction toward thermal power plants}

Renewable projects thus face high investment risks, while certain larger thermal power projects are categorized as public-private-partnership projects with additional build-operate-transfer (BOT) [b1, si1]. Up until mid-2018, these 20- to 25-year BOT contracts were completely underwritten by government guarantees [si1]. Because large power projects are considered strategic infrastructure [si8, si1], the Prime Minister included many of them in the list of priority 
projects for which he raised the limit of foreign loan guarantees (Vietnam Investment Review, 2018). Thus, BOT contracts represent the only reliable proof of investment for independent producers [si2, si1]. The resulting investment climate seems to be suitable especially for government-backed investors and financers from China, Japan and South Korea [sn1, sn3].

\section{Fiscal consolidation through environmental tax increases}

In order to reduce the debt burden and environmental pollution, the Finance Ministry has, in the past, advocated to increase the existing environmental protection taxes on fossil fuels [b1, si4, p3]. Increasing the environmental tax levels for coal could potentially shift cost competitiveness toward less polluting energy sources. The environmental tax revenues accounted for more than 4 percent of the total budget revenues in 2016 (up from 2.7 percent in 2015), but only 2 percent of the revenues were from the coal tax (Government of Vietnam, 2017). Despite marginal increases, the tax levels of USD 1.3 (VND 30,000) per ton of anthracite and US $\not 60$ (VND 15,000) per ton of lignite [p3] do not impact electricity sector decisions [si5].

Meaningful tax levels would clash with the Party's strife for low electricity tariffs. The government voiced concerns that tax increases might negatively affect industrial competitiveness and raise consumer prices and inflation [p3, p4, p2, p6, b2]. Referring to the carbon tax considered (World Bank, 2019a), an Environment Ministry representative told us that "Vietnam is not ready" and "due to the low income of the population, subsidies are necessary". An increase in the coal tax (or the removal of indirect subsidies) is thus unlikely in the near future $[\mathrm{p} 5, \mathrm{si}, \mathrm{p} 2]$.

\section{Security of supply}

"Keeping the lights on" [si1] for citizens, and providing sufficient electricity to sustain high economic growth rates, was generally voiced as an important pillar of the CPV's energy policy, and as pivotal for the Party's strategy to legitimize and maintain its power [si1, si3, p5, p1]. The narrative that high levels of energy supply growth constitute a necessary prerequisite, if not a main driver, for economic growth (e.g. World Economic Forum, 2012) is widely adopted among government officials [p8]. The importance of this goal is most visible in the symptomatic overestimation of electricity demand growth, mostly due to overestimated economic growth expectations and conservative energy conservation assumptions. While the PDPVII Revised adjusted the total annual generation by 2030 downward by 18 percent, it is still likely to overestimate demand growth [sn1] (Neefjes \& Thi Thu Hoai, 2017). Anecdotal evidence from the development process of the PDPVII indicates that political interventions, especially by the Prime Minister, are the main reason for continued overestimations [si8], allegedly, requesting to raise expected year-to-year demand growth from 
12 to 20 percent due to higher expected GDP growth [p1]. The political goal to supply sufficient electricity is influencing developments in the generation mix in several ways.

\section{Coal perceived as stable and well-known}

Apart from hydropower, which has traditionally supplied the bulk of electricity, coal is the single most trusted source of electricity generation [p2, si1, si5], despite concerns related to increasing dependence on imports. At EVN, in the Energy Ministry, and even the Environment Ministry, "most experienced experts want coal" [p1], saying "the solution to [electricity supply] issues is clean coal" [p8]. They know the technology well and are comforted by its proven track record of ensuring stable electricity supply in Vietnam's (seasonally fluctuating) hydro-based system [sn1]. At the same time, the Party's Committee on Economics has acknowledged energy security in terms of dependence on coal imports as a strategic concern [sn1,p8]. This is especially relevant as the Energy Ministry, for the first time in six years, warned of power shortages as early as 2019. Vinacomin's inability to keep pace with the growing demand for coal supply has forced some facilities to run at lower load factors (VnExpress, 2018). Structural supply bottlenecks are expected after 2021/2022 due to delays in the construction of several strategic power plants, as well as insufficient transport capacity for coal imports [si8, si1, b4, si6]. This has to some degree contributed to renewable energy being viewed as relevant in order to diversify the generation mix and relieve the pressure on coal supply [p2].

\section{Uncertainty about renewables' grid integration potential}

The same circle of senior experts advocating for coal in the Energy Ministry and $\mathrm{EVN}$ is quite outspoken in their concerns regarding intermitted renewables. In their opinion, more than 10 percent renewable electricity generation, as planned in the PDP VII by 2030, could destabilize the transmission system and interrupt supply [p5, sn1]. This sentiment partly owes to the centralized five- to ten-year plans governing the electricity sector; forward planning of regionally balanced supply between North, South and CentralVietnam is easier if serviced by a few large power stations rather than multiple fluctuating small installations [p1]. Independent experts, however, expect that problems of system load, ancillary services and, in particular, a lack of human capacity for grid management would only arise at renewables shares well above 20 percent [si8, si7]. There is, however, a lack of information disclosure by EVN. ${ }^{6}$ This means that independent analyses are hampered by information asymmetries and uncertainty about technical parameters and data [p1]. Even the CPV and its advisory committees, which constitute the highest decision-making bodies, are not well informed, as they also rely on judgment from experts within the Energy Ministry and EVN [b4, sn2]. 


\section{Promotion of the domestic energy industry and personal interests}

The strong incumbent resistance to transition is the implicitly underlying reason behind many of the above-described regulatory biases in favor of fossil energy carriers. Yet, this goal to promote the existing domestic energy enterprises is less explicitly articulated because it is often linked to incumbent vested interests and personal benefits [b4, b3, b1, si1, si5, si6, sn1].

\section{"Revolving door" with EVN and weak regulation}

The main cause for the weak regulation and protracted reform of EVN, Vinacomin and PVN is the "revolving door" [si1], that is, the frequent exchange of senior personnel, between the Energy Ministry, its SOEs and their subsidiaries along the electricity supply chain [si5, b3, b1] (c.f. also Heger, 2017). Thus, due to close personal ties, the regulating and regulated entities share strong, also personal, interests. Interviewees described this network as a "group of beneficiaries" [si5] or "invested group" [sn1], built around fossil fuels with an interest in maintaining the status quo [b1]. Within this group, EVN is the most powerful player and "barrier of the country" to energy sector reform [si5, b4]. Due to its strong influence on the Energy Ministry, representatives of the Ministry's renewables department and the - officially independent - Institute of Energy are reluctant to mandate policies that might contradict EVN's interests, even if they personally do not have direct ties to SOEs [si5].

Several interviewees highlighted that one of the major streams of (mostly personal) revenue originates from the lack of transparency along the coal supply chain [si1, b1, b3, b5]. For example, EVN or Vinacomin might import coal at more beneficial conditions, that is, lower prices or higher exchange rates or at lower quantities than actually reported [b1,b3]. In another example,Vinacomin's provincial mines do not have to report deals of up to USD 1 million to higher levels [b3].The SOEs' deficits from such nontransparent practices are eventually covered by the government. Some of these funds are channeled to high-ranking officials in the Energy Ministry as well as to members of the Party's Central Committee. These "invested" actors hence have little incentive to enforce transparent information disclosure (required by the government-issued Decree 81/ 2015/ND-CP) or reform the electricity sector [p 8, si5, b1, sn1, si6].

The Planning and the Finance Ministries openly criticize the low quality of reporting by the SOEs to the government. They claim that, because information disclosure duties are not enforced, financial reporting is insufficient to assess the transparency of SOEs (U.S. Department of State, 2018). Yet, the Planning and the Finance Ministries are not in a position to promote meaningful change in the energy sector, which could only be initiated by the CPV [p 8, sn1, si5, si4]. Thus, the institutional and personal interests in maintaining the status quo not only conflict with the main goals of ensuring reliable and affordable electricity supply but these interests also directly promote fossil, mostly coal-based, generation additions. 
Complex permitting process and favoritism

The complex, costly and time-consuming permitting and approval process for new generation facilities further hampers investments in Vietnam's generation capacity [si2, b1]. Apart from financing bottlenecks, bureaucratic delays throughout the permitting process are one of the reasons for the current delays in the construction of at least ten coal-fired power plants [b4, p8, si3]. Those delays cause additional stress on Vietnam's power supply starting in 2022 [b4]. Obtaining all necessary licenses normally takes between six and ten years. New power projects first need approval by the respective provincial administration. They are then incorporated in the Provincial Power Development Plan by the provincial Energy Ministries to receive a construction license and grid connection. Generation facilities larger than $50 \mathrm{MW}$ require additional approval on the national level [p1, p8, si5].

Public procurement in Vietnam's natural resources sector, which all energy SOEs are directly or indirectly involved in, bears especially high risk of corruption, diversion of funds and favoritism and, respectively, a lack of accountability in the licensing regime [b4, si2] (Bertelsmann Stiftung, 2018). The Provincial Competitiveness Index consistently finds that in order to secure government contracts the majority of companies expect to provide "gifts" to officials and strong ties to provincial governments are necessary. Additionally, private sector firms face less favorable terms than SOEs regarding access to, for example, land and capital (VCCI, 2017).

Apart from the investment risks described, the corruption-prone process poses an additional hurdle for smaller, nonfossil IPPs but gives an advantage to, particularly state-affiliated, investors in thermal coal [sn1]. Local renewable energy investors with limited equity often struggle to afford additional (informal) upfront charges [sn3]. International firms interested in tapping Vietnam's renewable potential are often prohibited to pay such charges according to their corporate MOUs [b1]. However, Chinese state-owned and Korean and Japanese enterprises and banks successfully conduct business in Vietnam. Having established good ties with the Party representatives at local and national levels, they provide one of the few available sources of capital in the described context of favoritism and political uncertainty [si6, si2, sn1, b4] (c.f. Hannam et al., 2015). A 2014 National Assembly report found that over 90 percent of public procurement went to Chinese firms (U.S. Department of State, 2017) and nine out of ten renewable energy installations in Vietnam reportedly use Chinese equipment [si1]. Hence, for the period of the PDP VII Revised (2016-2020/2030), the majority of foreign direct investment in the electricity sector is targeted at thermal coal power plants. For example, the latest 25-year thermal BOT contract with EVN was signed by a consortium of the Japan Bank for International Cooperation (JBIC), the OverseaChinese Banking Corporation Limited and the Bank of China in April 2019 (JBIC, 2019). Negotiations for this USD 2 billion coal plant investment initially started in 2011 . 


\section{Climate and environmental objectives}

Vietnam's various policy plans and strategies related to climate change mitigation have neither affected greenhouse gas (GHG) emissions growth nor the pipeline of additional coal-fired capacity. Local environmental and health concerns, in contrast, have effectively deterred the construction of a few coal power plants in some provinces. Yet, environmental and climate considerations exert little influence on electricity sector planning.

Vague, inconsistent and weakly implemented emission reduction targets

Vietnam's several strategies relating to sustainable development have been largely detached from electricity sector planning, lack consistency and implementation, and are thus unlikely to curb the coal pipeline. There is a lack of integration between sectoral planning documents, which owes to an institutional separation between the line ministries, described as a silo mentality [si8, b3].The Climate Change Strategy (CCS) (Government of Vietnam, 2011) and the Nationally Determined Contributions (NDC) (MONRE, 2015) are with the Environment Ministry, the Green Growth Strategy (GGS) (Government of Vietnam, 2012) with the Planning Ministry, and the Renewable Energy Development Strategy (REDS) (Government of Vietnam, 2015) is with the Energy Ministry. These strategies formulate targets differently with regard to GHG emission reductions or intensity improvements. Moreover, they refer to varying business-as-usual (BAU) assumptions that are subject to controversies between different government agencies [p2, si6].

For the electricity sector, the formulated supply-side goals are to diversify the generation mix to reduce import dependency rather than reduce emissions or the coal pipeline [p2, si8, si5]. The aim is to increase renewables and reduce coal exports and imports (c.f. REDS, GGS). Instead "the most important [mitigation] options are [seen] on the demand side" [p2]. These include energy efficiency measures and fuel switching in the industry and transport sectors, as well as land-use change [b2, p5, p6]. However, efforts on the electricity demand side, especially industrial energy efficiency improvements, are undermined by electricity sector policies. Most prominently, the regulated, extremely low electricity and coal prices provide few incentives for energy savings [p2, si8, si3, b4]. According to a financial sector expert, the indirect subsidies for fossil fuels of several billion USD annually are an important reason why energy and environment plans are not consistent.

Finally, weak implementation and enforcement render many strategies and plans rather ineffective [si4, p5] or, as one interviewee put it, there is "no correlation" between plans and reality $[\mathrm{b} 1] .{ }^{7}$ Even interviewees from government institutions stressed that the goals are largely statements of intent "only on paper" [p8, p5] and even environmental goals that have been translated into law are often not enforced due to a lack of political will [b1, si2, si5, p8]. 
Reciprocal interests with international donors

Many of Vietnam's environment-related strategies were initiated by international development agencies [b1], whose (conditional) financial assistance has historically accounted for a sizable share of the government budget. However, the interaction of government and donor interests has in the past contributed to contradictory outcomes for several reasons. The Vietnamese government, on the one hand, has shown great interest in attracting further development finance with favorable borrowing conditions, especially after the country's recent graduation from two low-interest funds ${ }^{8}[\mathrm{p} 4$, si2]. The donor organizations, on the other hand, are themselves interested in continuing to lend [si2] (e.g. Rahman \& Giessen, 2017). For example, EVN received direct financial and advisory support to prepare for its credit rating (World Bank, 2018); it received an issuer default rating of "BB", equivalent to the government's rating. The rating is sufficient for EVN to access foreign loans, especially from international financial institutions, without additional guarantees [si3].

The reciprocal interests have created contradictory incentives on both sides. First, the government is incentivized to approve environment-related policy plans that specifically meet the donors' requirements in order to tap into the increased volumes of environmental development policy financing ${ }^{9}[\mathrm{~b} 1]$. However, most of this results-based support has been tied to policy outputs, rather than outcomes, that is, to the approval, but not necessarily to the subsequent implementation of policy decisions [si2, si8, b4] (c.f. Independent Evaluation Group, 2016). Second, in order to single out their contribution and prove aid effectiveness, donors have been reluctant to coordinate their efforts [si8] (c.f. Fuchs et al., 2015). Such policy-oriented efforts have significantly contributed to the silo mentality between government agencies as they compete for financing, as well as to the incoherence between environmental and energy planning documents [b3, si1]. Third, the weakly conditional financial support hampers political reform as it relieves financial pressure from the government and SOEs [si2, b4]. For example, of EVN's USD 9 billion debt (2016), 90 percent are backed by the Finance Ministry, the majority of which are directly on-lent funds from international financial institutions (Gerner et al., 2018) As suggested in the literature, despite the well-known misappropriation and ineffectiveness of funds, many donors are continuing to (indirectly) fund the fossil-based system as it seems to serve their own interests, such as the continued outflow of funds (c.f. Rahman \& Giessen, 2017; Swedlund, 2017). ${ }^{10}$ These substantial financial flows are likely to strengthen the existing incumbent resistance to transition and thus render (environmental) development policy financing ineffective [si4].

Effective local public resistance against coal-fired power plants

While international efforts might not have deterred Vietnam's coal plans, the formation of local public resistance has effectively pushed some local 
Provincial Party Committees to cancel already approved coal-fired power projects and oppose new ones. In some provinces, especially in Southern Vietnam, public opposition is increasing due to concerns of degrading local air quality, as well as environmental harm from wastewater and ash and slag discharge [sn2]. In particular, Vietnam-based nongovernmental organizations (NGOs) have successfully focused their climate change, mitigation-related advocacy work at the community and province levels [sn1, sn2]. While some provincial governments have subsequently advocated for renewables and gas-fired power additions with the national Party cadre, others, in regions depending on coal mining, exert equally strong influence on the national level in favor of coal [b3, si4]. Nationally, the Prime Minister prominently advocated for a moratorium on new coal-fired power plants in the Mekong Delta after 2020 [b1, si2, p5].

\section{Conclusion}

This analysis of Vietnam's energy and climate governance reveals that the motivation to expand coal-fired capacity goes far beyond (or even contradicts) economic cost criteria and it is rather determined by the state's control over the energy sector, incumbent networks, and international enabling environments. We find that Vietnam's focus on coal for electricity generation is primarily driven by the incumbent networks between decision-makers in the Communist Party, the Ministry of Industry and Trade ("Energy Ministry"), responsible for regulating the energy sector, and the state-owned energy enterprises (SOEs). Financial and structural constraints lead to a strong dependence on - mostly international - independent power producers for capacity additions. Yet, barriers for renewable energy investors remain high because market regulations are volatile and tailored to the needs of fossil-leaning energy SOEs. International and local environmental efforts exert limited influence on the energy sector. Concessional development policy financing creates incentives for weakly integrated and hardly enforced environmental strategies. Additionally, direct budget support to SOEs relieves to some extent the financial pressure to reform. Despite this combination of factors that consolidate Vietnam's reliance on coal, some recent developments could gradually change policymakers' incentives. First, declining prices for clean energy sources in conjunction with increased fiscal pressure and warnings of electricity shortages may accelerate renewables' build-up - around $6 \mathrm{GW}$ of grid-connected solar had been built at the time of writing - as well as the liberalization of the power market. Second, a shift of financial support from international donors and investors away from coal could result in a further expansion of renewables. Third, public concern about climate change and environmental pollution could provide an important motivation for the Communist Party to reconsider its focus on coal-based power generation. 


\section{Acknowledgments}

The authors would like to thank all interviewees and translators for their valuable contributions without which this case study could not have been conducted. Further thanks to William Lamb, the participants of the 2018 Annual Meeting of the Environment for Development (EfD) Initiative in Hanoi and the 2019 European Consortium for Political Research's (ECPR) General Conference in Wroclaw for helpful comments and suggestions and Justyna Grosjean for her kind logistical support. We thank Niccolò Manych for excellent research assistance. We gratefully acknowledge funding from the German Federal Ministry of Education and Research (BMBF), funding code 01LS1610B (pep 1.5). Ira Dorband also acknowledges financial support by the Heinrich Böll Foundation.

\section{Appendix}

This chapter contains supplementary online material at https://www.mcc-berlin. net/pecoal/ch12.

\section{Notes}

1 This chapter draws on the article Dorband et al. (2020). We gratefully acknowledge permission to reproduce parts of the content from Elsevier.

2 We transcribe all but five of the interviews in which the interviewees refused or seemed reluctant to speak openly when recorded. We guarantee the anonymity of all interview partners.

3 Note that we count each interviewee mentioning a specific objective as one mentioned, irrespective of how many times during the interview the objective was mentioned.

4 The 2006 RoadMap for Power Sector Reforms envisages a fully competitive wholesale market by 2021 and retail market by 2023 .

5 EVN has to provide the connection to the close-by substation, while developers themselves are responsible for the immediate electricity line to the substation. This can be costly for remote renewables and wind.

6 EVN does not disclose key data, for example, on actual demand, production costs or system data. For example, the Institute of Energy, which is mandated with electricity system modeling and drafting the PDPs, is required to schedule interviews with EVN representatives in order to receive such data, according to an interviewed expert from the Institute.

7 Examples of plans, the implementation of which is extremely delayed or continued to be postponed, are the GGS and the Roadmap to Liberalize the Electricity Market (si4).

8 From the World Bank's International Development Association and the Asian Development Bank's Asian Development Fund.

9 "Development Policy Financing [...] is intended to achieve development results primarily through the supported policy reforms and associated policy dialog and support" (Independent Evaluation Group, 2016, p. 1). 
10 Recent examples of assistance, the effectiveness of which were called into question by interviewees, included: (i) USD 340 million of direct budget support by the EU, (ii) substantial financial support to the Finance Ministry to guarantee further debt of EVN by the World Bank and (iii) a USD 100 million loan from the same organization, guaranteed by the Green Climate Fund with another USD 75 million (Green Climate Fund, 2019), for energy-efficient equipment in the SOE-dominated steel and cement industries. (si2, b4).

\section{References}

ADB. (2015). Assessment of Power Sector Reform in Vietnam: Country Report. Asian Development Bank (ADB).

Bertelsmann Stiftung. (2018). Transformation Index BTI 2018: Vietnam Country Report. Verlag Bertelsmann Stiftung.

Bogner,A., Littig, B., \& Menz, W. (2018). Generating Qualitative Data with Experts and Elites. In U. Flick (Ed.), The SAGE Handbook of Qualitative Data Collection. SAGE Publications Ltd., 652-667. https://doi.org/10.4135/9781526416070

Dorband, I. I., Jakob, M., \& Steckel, J. C. (2020). Unraveling the political economy of coal: Insights from Vietnam. Energy Policy, 147, 111860.https://doi.org/10.1016/ j.enpol.2020.111860

EVN. (2018). Annual Report 2017.Vietnam Electricity (EVN). https://en.evn.com.vn/ d6/news/Annual-Report-2017-6-13-839.aspx

EVN. (2019). Retail Electricity Tariff. https://en.evn.com.vn/d6/gioi-thieu-d/RETAILELECTRICITY-TARIFF-9-28-252.aspx

Fuchs, A., Nunnenkamp, P., \& Öhler, H. (2015). Why donors of foreign aid do not coordinate: The role of competition for export markets and political support. The World Economy, 38(2), 255-285.

Gerner, F., Gibert, M., Alatabani, A. F., Behrend, O. P., Eckardt, S., \& Santley, D. J. (2018). Vietnam - Maximizing Finance for Development in the Energy Sector. World Bank Group. http://documents.worldbank.org/curated/en/897271548259738578/ Vietnam-Maximizing-Finance-for-Development-in-the-Energy-Sector

Government ofVietnam. (2011). Prime Minister Decision 2139/QD-TTg of 05/12/2011, on Approval of the National Climate Change Strategy. http://extwprlegs1.fao.org/docs/ pdf/vie113168.pdf

Government of Vietnam. (2012). Prime Minister Decision 1393/QD-TTg 25/09/2012, on Approval of National Strategy of Green Growth 2011-2020 with outlook to 2050.

Government of Vietnam. (2015). Prime Minister Decision 2068/QĐ-TTg, 25 November 2015 on Approval of the Viet Nam Renewable Energy Development Strategy up to 2030 with an outlook to 2050 (REDS).

Government ofVietnam. (2017). Assessment Report on Implementation of the Environmental Protection Tax. http://duthaoonline.quochoi.vn/DuThao/Lists/DT_DUTHAO_ LUAT/View_Detail.aspx?ItemID $=1310 \&$ TabIndex $=2 \&$ TaiLieuID $=2763$

Green Climate Fund. (2019). FP071 Scaling Up Energy Efficiency for Industrial Enterprises in Vietnam [Text]. Green Climate Fund. www.greenclimate.fund/projects/fp071

GreenID. (2018). Analysis of Future Generation Capacity Scenarios for Vietnam. Green Innovation and Development Centre (GreenID). http://en.greenidvietnam.org.vn/ app/webroot/upload/admin/files/060618_GreenID_Study\%20on\%20future\%20 power\%20sources.pdf 
Hannam, P. M., Liao, Z., Davis, S. J., \& Oppenheimer, M. (2015). Developing country finance in a post-2020 global climate agreement. Nature Climate Change, 5(11), 983987. https://doi.org/10.1038/nclimate2731

Heger, K. (2017). Corruption Risks in Vietnam's Energy Sector. Transparency International. www.transparency.org/files/content/corruptionqas/Corruption_Risks_in_ Vietnams_Energy_Sector.pdf

IEA. (2017). World Energy Balances. IEA. www.oecd-ilibrary.org/energy/energybalances-of-non-oecd-countries-2017_energy_bal_non-oecd-2017-en

IEA. (2018). World Energy Outlook 2018. International Energy Agency (IEA). https:// doi.org/10.1787/weo-2018-en

Independent Evaluation Group. (2016). Lessons from Environmental Policy Lending. The World Bank. https://ideas.repec.org/b/wbk/wbpubs/24926.html

Jakob, M., Flachsland, C., Christoph Steckel, J., \& Urpelainen, J. (2020). Actors, objectives, context: A framework of the political economy of energy and climate policy applied to India, Indonesia, andVietnam. Energy Research E Social Science, 70, 101775. https://doi.org/10.1016/j.erss.2020.101775

JBIC. (2019, April 19). Project Finance for Van Phong 1 Coal-Fired Power Generation Project in the Republic of Vietnam. Press Release Japan Bank for International Cooperation (JBIC). www.jbic.go.jp/en/information/press/press-2019/0419-012106.html

Jenkins, J. D. (2014). Political economy constraints on carbon pricing policies: What are the implications for economic efficiency, environmental efficacy, and climate policy design? Energy Policy, 69, 467-477. https://doi.org/10.1016/j.enpol.2014.02.003

Joas, F., Pahle, M., Flachsland, C., \& Joas, A. (2016). Which goals are driving the Energiewende? Making sense of the German Energy Transformation. Energy Policy, 95, 42-51. https://doi.org/10.1016/j.enpol.2016.04.003

Johnstone, P., Stirling,A., \& Sovacool, B. (2017). Policy mixes for incumbency: Exploring the destructive recreation of renewable energy, shale gas 'fracking,' and nuclear power in the United Kingdom. Energy Research \& Social Science, 33, 147-162. https://doi. org/10.1016/j.erss.2017.09.005

Koplitz, S. N., Jacob, D. J., Sulprizio, M. P., Myllyvirta, L., \& Reid, C. (2017). Burden of disease from rising coal-fired power plant emissions in Southeast Asia. Environmental Science \& Technology, 51(3), 1467-1476. https://doi.org/10.1021/acs.est.6b03731

Maweni, J., \& Bisbey, J. (2016). A Financial Recovery Plan for Vietnam Electricity (EVN): With Implications for Vietnam's Power Sector. World Bank Group. http:// documents.worldbank.org/curated/en/971901468196178656/A-financialrecovery-plan-for-Vietnam-Electricity-EVN-with-implications-for-Vietnam-spower-sector

MONRE. (2015). Technical Report:Viet Nam's Intended Nationally Determined Contribution. Ministry of Natural Resources and Environment (MONRE).

Nangia, R. (2019). Securing Asia's energy future with regional integration. Energy Policy, 132, 1262-1273. https://doi.org/10.1016/j.enpol.2019.06.007

Neefjes, K., \& Thi Thu Hoai, D. (2017). Towards a Socially Just Energy Transition in Viet Nam. Challenges and Opportunities. Friedrich Ebert Stiftung. http://library.fes.de/pdffiles/bueros/vietnam/13684.pdf

News VietNamNet. (2016, April 1). Government to Sstop Pproviding Gguarantee for Lloans to SOEs. https://english.vietnamnet.vn/fms/business/152885/government-tostop-providing-guarantee-for-loans-to-soes.html

Rahman, M. S., \& Giessen, L. (2017). Formal and informal interests of donors to allocate aid: Spending patterns of USAID, GIZ, and EU forest development 
policy in Bangladesh. World Development, 94, 250-267. https://doi.org/10.1016/j. worlddev.2017.01.012

Schmidt, T. S., Schmid, N., \& Sewerin, S. (2019). Policy goals, partisanship and paradigmatic change in energy policy - Analyzing parliamentary discourse in Germany over 30 years. Climate Policy, 1-16. https://doi.org/10.1080/14693062.2019.1594667

Shearer, C., Myllyvirta, L., Yu, A., Dallos, G., Aitken, G., Mathew-Shah, N., \& Nace, T. (2020). Boom and Bust 2020: Tracking the Global Coal Plant Pipeline. Global Energy Monitor, Sierra Club, Greenpeace, CREA.

Swedlund, H. J. (2017). Can foreign aid donors credibly threaten to suspend aid? Evidence from a cross-national survey of donor officials. Review of International Political Economy, 24(3), 454-496. https://doi.org/10.1080/09692290.2017.1302490

Tang, C. F., Tan, B. W., \& Ozturk, I. (2016). Energy consumption and economic growth in Vietnam. Renewable and Sustainable Energy Reviews, 54, 1506-1514. https://doi. org/10.1016/j.rser.2015.10.083

UNDP. (2019). Bottlenecks Assessment and Solutions to Accelerate Implementation of Paris Agreement in Viet Nam. United National Development Programme (UNDP). www.vn.undp.org/content/vietnam/en/home/library/environment_climate/ bottlenecks-assessment-and-solutions-to-accelerate-implementatio.html

Urban, F., Siciliano, G., Wallbott, L., Lederer, M., \& Dang Nguyen, A. (2018). Green transformations in Vietnam's energy sector. Asia \& the Pacific Policy Studies, 5(3), 558582. https://doi.org/10.1002/app5.251

U.S. Department of State. (2017). Investment Climate Statement (ICS) 2017: Vietnam. Bureau of Economic and Business Affairs, U.S. Department of State. www.state.gov/ reports/2017-investment-climate-statements/_trashed/

U.S. Department of State. (2018). Investment Climate Statements (ICS) 2018: Vietnam. Bureau of Economic and Business Affairs, U.S. State Department. https://pa-public. state.gov/mystatedept/reports/pdfreport_3216.pdf

VCCI. (2017). Provincial Competitiveness Index (PCI) 2017. Vietnam Chamber of Commerce and Industry (VCCI) \& United States Agency for International Development (USAID). http://eng.pcivietnam.org/publications/full-report-2017/

Viet Nam News. (2019, July 15). Solar power glut overloads power transmission lines in Ninh Thuận, Bình Thuận. Vietnamnews. Vn.

Vietnam Investment Review. (2018, July 5). Foreign loans in Vinh Tan 4 expansion may get government guarantee. Vietnam Investment Review under Ministry of Planning and Investment. www.vir.com.vn/foreign-loans-in-vinh-tan-4-expansion-may-getgovernment-guarantee-60676.html

VnExpress. (2018, November 28). Coal shortage could sap Vietnam's energy. VnExpress International - Latest News, Business, Travel and Analysis from Vietnam. https:// e.vnexpress.net/news/business/industries/coal-shortage-could-sap-vietnam-senergy-3846007.html

Vu, K. (2019, March 20). UPDATE 1-Vietnam Hikes Retail Electricity Prices by 8.36 pct -Ministry. Reuters. www.reuters.com/article/vietnam-energy-pricesidUSL3N2172E1

World Bank. (2018, June 7). Vietnam Electricity (EVN) Achieves its First and Positive Credit Rating from Fitch Ratings. www.worldbank.org/en/news/press-release/2018/06/ 07/vietnam-electricity-evn-achieves-its-first-and-positive-credit-rating-from-fitchratings 
World Bank. (2019a). State and Trends of Carbon Pricing 2019. World Bank Group.

World Bank. (2019b). World Development Indicators | Data. http://data.worldbank.org/ indicator

World Economic Forum. (2012). Energy for Economic Growth: Energy Vision Update 2012-Industry Agenda.

Zimmer,A., Jakob, M., \& Steckel,J. C. (2015).What motivatesVietnam to strive for a lowcarbon economy?-On the drivers of climate policy in a developing country. Energy for Sustainable Development, 24, 19-32. https://doi.org/10.1016/j.esd.2014.10.003 